\title{
SISTEM PENUNJANG KEPUTUSAN PEMILIHAN GURU TERBAIK DENGAN METODE TOPSIS (TECHNIQUE FOR ORDER PREFERENCE BY SIMILARITY TO IDEAL SOLUTION) STUDI KASUS : SDN BENDUNGAN HILIR O1 PAGI JAKARTA PUSAT
}

\author{
Hendri Ardiansyah \\ Teknik Informatika, Universitas Pamulang \\ email : hendri_ardiansyah@hotmail.com
}

\begin{abstract}
ABSTRAK
Tugas utama guru adalah mendidik, mengajar, membimbing, mengarahkan, melatih, menilai, dan mengevaluasi peserta didiknya. Guru berprestasi adalah guru yang memiliki kemampuan melaksanakan tugas, keberhasilan dalam melaksanakan tugas, memiliki kepribadian yang sesuai dengan profesi guru dan memiliki wawasan kependidikan. Sistem pendukung keputusan atau Decision Support System (DSS) merupakan suatu sistem yang dapat membantu dalam pengambilan keputusan pada sebuah organisasi atau perusahaan dengan menerapkan metode yang sesuai dengan bidang keputusan yang diambil, Pengambilan keputusan secara manual tanpa bantuan SPK akan menghasilkan penilaian yang tidak objektif dan tidak tepat. Metode Technique for Order Preference by Similarity to Ideal Solution (TOPSIS) merupakan salah satu metode pengambilan keputusan multi kriteria dengan menerapkan bobot nilai pada setiap kriterianya. Pemilihan metode TOPSIS ini dibandingkan dengan metode SPK yang lain yaitu metode ini menggunakan prinsip bahwa alternatif yang terpilih harus mempunyai jarak terdekat dari solusi ideal positif dan jarak terjauh dari solusi ideal negatif. Sistem yang dibuat memungkinkan pihak sekolah untuk menentukan aspek penilaian berdasarkan kriteria sesuai dengan kebutuhan dari sekolah tersebut sehingga lebih fleksibel. Sistem pendukung keputusan dengan metode TOPSIS ini diharapkan dapat membantu dalam pemilihan guru terbaik.
\end{abstract}

Keyword : Guru, Sistem Penunjang Keputusan, TOPSIS.

\section{PENDAHULUAN}

\section{Latar Belakang}

Dalam upaya meningkatkan mutu pendidikan untuk para siswa sebagai generasi penerus bangsa dibutuhkan guru yang berkompeten dalam memberikan pendidikan kepada siswa, Tugas utama guru adalah mendidik, mengajar, membimbing, mengarahkan, melatih, menilai, dan mengevaluasi peserta didiknya Guru berprestasi adalah guru yang memiliki kemampuan melaksanakan tugas, keberhasilan dalam melaksanakan tugas, memiliki kepribadian yang sesuai dengan profesi guru dan memiliki wawasan kependidikan sehingga secara nyata mampu meningkatkan mutu proses dan hasil pembelajaran atau bimbingan melebihi yang dicapai oleh guru lain sehingga dapat dijadikan panutan siswa, rekan sejawat, maupun masyarakat sekitarnya. (Martaulina, 2015)

Sistem pendukung keputusan atau Decision Support System (DSS) merupakan suatu sistem yang dapat membantu dalam pengambilan keputusan pada sebuah organisasi atau perusahaan, di dunia pendidikan Sistem Penunjang Keputusan (SPK) dapat dipandang sebagai aset penting untuk menunjang kelancaran dan keakuratan dalam pencapaian suatu tujuan. Salah satunya adalah untuk menentukan atau penilaian guru terbaik, dengan menggunakan Sistem penunjang keputusan proses pemilihan guru terbaik akan semakin objektif dan tepat sasaran. Banyak metode yang digunakan dalam Sistem Penunjang keputusan seperti TOPSIS (metode Technique for Order Preference by Similarity to Ideal Solution), SAW(Simple Additive Weighting) dan AHP (Analytical Hierarchy Process). Salah satu metode yang banyak digunakan adalah Topsis karena merupakan salah satu metode pengambilan keputusan multi kriteria dengan menerapkan bobot nilai pada setiap kriterianya, metode ini menggunakan prinsip bahwa alternatif yang terpilih harus mempunyai jarak terdekat dari solusi ideal positif dan jarak terjauh dari solusi ideal negatif. Artinya pilihan akan diurutkan berdasarkan nilai yang dihasilkan sehingga 
alternatif yang memiliki jarak terpendek dengan solusi ideal positif adalah alternatif yang terbaik.

\section{Tujuan penelitian}

Tujuan dari penelitian ini adalah :

1. Untuk Membuat sistem pendukung keputusan pemilihan guru terbaik.

2. Untuk menerapkan metode Technique for Order Preference by Similarity to Ideal Solution (TOPSIS) pada sistem pendukung keputusan pemilihan guru terbaik.

\section{METODE PENELITIAN}

Metodelogi penelitian menggunakan metode TOPSIS (metode Technique for Order Preference by Similarity to Ideal Solution), dan metodelogi untuk Pembuatan sistem menggunkan metode waterfall.

TOPSIS merupakan metode pengambilan keputusan multikriteria menggunakan prinsip bahwa alternatif terpilih harus mempunyai jarak terdekat dari solusi ideal positif dan jarak terpanjang (terjauh) dari solusi ideal negatif untuk menentukan kedekatan relatif dari sudut pandang geometris dengan menggunakan jarak Euclidean (jarak antara dua titik) untuk menentukan kedekatan relatif dari suatu alternatif dengan solusi optimal. Solusi ideal positif didefinisikan sebagai jumlah dari seluruh nilai terbaik yang dapat dicapai untuk setiap atribut, sedangkan solusi ideal negatif terdiri dari seluruh nilai terburuk yang dicapai untuk setiap atribut.

\section{Tahapan TOPSIS}

1. Membuat matriks keputusan yang ternormalisasi.

$$
r_{i j}=\frac{x_{i j}}{\sqrt{\sum_{i=1}^{m} x_{i j}^{2}}} \ldots \ldots \ldots \ldots \ldots \ldots \text { (1) }
$$

Dengan $\mathrm{i}=1,2, \ldots, \mathrm{m}$; dan $\mathrm{j}=1,2, \ldots, \mathrm{n}$;

Dimana

rij = Elemen matriks ternormalisasi [i][j].

$\mathrm{xij}=$ Elemen matriks keputusan X.

2. Membuat matriks keputusan ternormalisasi terbobot.

$y_{i j}=w_{i} r_{i j} \ldots$

Dengan $\mathrm{i}=1,2, \ldots, \mathrm{m}$ dan $\mathrm{j}=1,2, \ldots, \mathrm{n}$;

Dimana

$y_{i j}=$ Elemen matriks ternormalisasi terbobot [i][j].

$\mathrm{wi}=$ Bobot $[\mathrm{i}]$
3. Menentukan matriks solusi ideal positif dan matriks solusi ideal negatif.

$$
\begin{aligned}
& A^{+}=\left(y_{1}^{+}, y_{2}^{+}, \ldots, y_{n}^{+}\right) ; \\
& A^{-}=\left(y_{1}^{-}, y_{2}^{-}, \ldots, y_{n}^{-}\right) ;
\end{aligned}
$$

Dimana

$y_{j}^{+}=\left\{\begin{array}{l}\max y_{i j} ; j \text { atribut keuntungan } \\ \min y_{i j} ; j \text { atribut biaya }\end{array}\right.$

$y_{j}^{-}=\left\{\begin{array}{l}\min y_{i j} ; j \text { atribut keuntungan } \\ \max y_{i j} ; j \text { atribut biaya }\end{array}\right.$

4. Menentukan jarak antara nilai setiap alternatif dengan matriks solusi ideal positif dan negatif.

Jarak antara alternatif ke-i dengan solusi ideal positif dirumuskan sebagai berikut:

$D_{i}^{+} \sqrt{\sum_{j=1}^{n}\left(y_{i j}-y_{i}^{+}\right)^{2}}$;

Dimana

$D_{i}^{+}=$Jarak alternatif ke-i dengan solusi ideal positif.

$y_{i}^{+}=$Elemen solusi ideal positif [i].

$y_{i j}=$ Elemen matriks ternormalisasi terbobot [i][j].

Jarak antara alternatif ke-i dengan solusi ideal negatif dirumuskan sebagai berikut:

$D_{i}^{-} \sqrt{\sum_{j=1}^{n}\left(y_{i j}-y_{i}^{-}\right)^{2}} ;$

Dimana

$D_{i}^{-}=$Jarak alternatif ke-i dengan solusi ideal negatif.

$y_{i}^{-}=$Elemen solusi ideal negatif [i].

$y_{i j}=$ Elemen matriks ternormalisasi terbobot [i][j].

5. Menentukan nilai preferensi untuk setiap alternatif.

Nilai preferensi untuk setiap alternatif(Vi) diberikan sebagai berikut:

$$
V_{i} \frac{D_{i}}{D_{i}^{-}+D_{i}^{+}}
$$

Dimana

$V_{i}=$ Kedekatan tiap alternatif terhadap solusi ideal.

$D_{i}^{+}=$Jarak alternatif ke-i dengan solusi ideal positif.

$D_{i}^{-}=$Jarak alternatif ke-i dengan solusi ideal negatif.

Nilai $V_{i}$ yang lebih besar menunjukan bahwa alternatif ke-i lebih dipilih.

\section{Tahapan Waterfall}


1. System Engineering.

mempersiapkan segala hal yang diperlukan dalam pelaksanaan proyek.

2. Analysis.

menganalisis segala hal yang ada pada pembuatan atau pengembangan proyek perangkat lunak yang bertujuan untuk memahami sistem yang ada, mengidentifikasi masalah dan mencari solusinya.

3. Design.

Merupakan tahapan yang menerjemahkan keperluan atau data yang telah dianalisis ke dalam bentuk yang mudah dimengerti oleh pemakai (user).

4. Coding.

Merupakan tahapan yang menerjemahkan data yang dirancang ke dalam bahasa pemrograman yang telah ditentukan.

5. Testing.

Merupakan tahapan pengujuan terhadap sistem atau program yang telah selesai dibuat.

6. Maintenance.

Merupakan tahapan menerapkan sistem secara keseluruhan disertai pemeliharaan jika terjadi perubahan struktur, baik dari segi software maupun hardware.

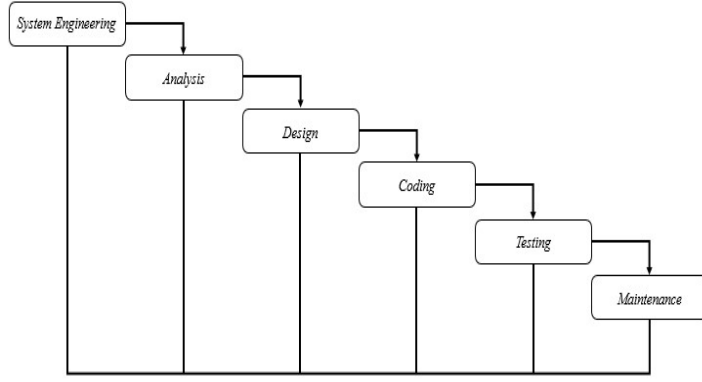

Gambar 1 Tahapan Waterfall

3. HASIL DAN PEMBAHASAN Analisa Sistem Pendukung Keputusan dengan Metode TOPSIS

Kriteria dan Bobot

Tabel 11. Kriteria

\begin{tabular}{cl} 
Kriteria & \multicolumn{1}{c}{ Keterangan } \\
C1 & Absensi \\
C2 & Pengembangan Kurikulum \\
C3 & Kemampuan Memotivasi \\
C4 & Tanggung Jawab \\
C5 & Penguasaan Materi
\end{tabular}

Penentuan kriteria berdasarkan bilangan fuzzy, seperti ditunjukan gambar berikut :

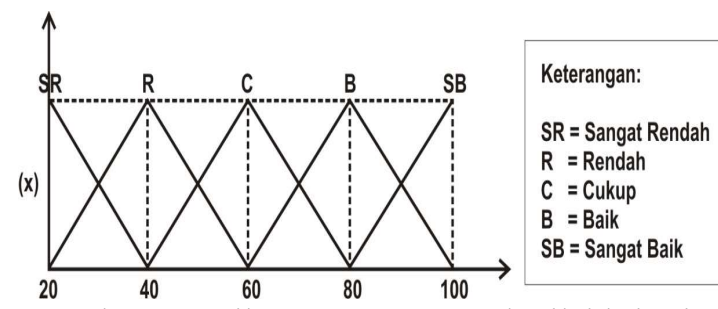

Gambar 16. Bilangan Fuzzy untuk nilai kriteria

Konversi nilai kriteria Fuzzy ke skor

Tabel 12. Skor Nilai Kriteria

$\begin{array}{ccc}\begin{array}{c}\text { Rentang } \\ \text { Nilai }\end{array} & \text { Skor } & \text { Keterangan } \\ 20< & 1 & \text { Sangat Rendah } \\ \geq 20 & 2 & \text { Rendah } \\ \geq 40 & 3 & \text { Cukup } \\ \geq 60 & 4 & \text { Baik } \\ \geq 80 & 5 & \text { Sangat Baik }\end{array}$

Tabel 13. Tabel Bobot

\begin{tabular}{cc} 
Skor & Keterangan \\
\hline 1 & Sangat Rendah \\
2 & Rendah \\
3 & Cukup \\
4 & Baik \\
5 & Sangat Baik
\end{tabular}

Data Sampling diambil hanya 5 orang dari total jumlah guru sebanyak 40 orang.

Tabel 14. Data Sampling

Kriteria

$\begin{array}{cccccc}\text { Alt } & \text { C1 } & \text { C2 } & \text { C3 } & \text { C4 } & \text { C5 } \\ \text { A1 } & 4 & 5 & 3 & 2 & 3 \\ \text { A2 } & 4 & 3 & 5 & 5 & 3 \\ \text { A3 } & 3 & 5 & 4 & 2 & 4 \\ \text { A4 } & 5 & 3 & 3 & 4 & 4 \\ \text { A5 } & 5 & 4 & 3 & 3 & 3 \\ \text { W } & 4 & 3 & 5 & 4 & 4\end{array}$

Hasil Matriks Ternormalisasi, menggunakan rumus : 


$$
r_{i j}=\frac{x_{i j}}{\sqrt{\sum_{i=1}^{m} x_{i j}^{2}}} \ldots \ldots \ldots \ldots \ldots \ldots(7)
$$

Tabel 15. Matriks ternomalisasi

\begin{tabular}{|l|l|l|l|l|}
\hline \hline 0.044 & 0.060 & 0.044 & 0.034 & 0.051 \\
\hline 0.044 & 0.036 & 0.074 & 0.086 & 0.051 \\
\hline 0.033 & 0.060 & 0.059 & 0.034 & 0.068 \\
\hline 0.055 & 0.036 & 0.044 & 0.069 & 0.068 \\
\hline 0.055 & 0.048 & 0.044 & 0.052 & 0.051 \\
\hline
\end{tabular}

Hasil Matriks Ternormalisasi terbobot menggunakan rumus :

$$
y_{i j}=w_{i} r_{i j}
$$

Tabel 16. Matriks Ternormalisai Terbobot

\begin{tabular}{|l|l|l|l|l|}
\hline 0.176 & 0.179 & 0.221 & 0.138 & 0.203 \\
\hline 0.176 & 0.107 & 0.368 & 0.345 & 0.203 \\
\hline 0.132 & 0.179 & 0.294 & 0.138 & 0.271 \\
\hline 0.220 & 0.107 & 0.221 & 0.276 & 0.271 \\
\hline 0.220 & 0.143 & 0.221 & 0.207 & 0.203 \\
\hline
\end{tabular}

Hasil perhitungan solusi ideal posistif menggunakan rumus :

$$
\begin{aligned}
& A^{+}=\left(y_{1}^{+}, y_{2}^{+}, \ldots, y_{n}^{+}\right) ; \\
& A^{-}=\left(y_{1}^{-}, y_{2}^{-}, \ldots, y_{n}^{-}\right) ;
\end{aligned}
$$

Tabel 17. Solusi ideal positif

$\begin{array}{ll}y_{1}^{+} & 0.21978 \\ y_{2}^{+} & 0.17857 \\ y_{3}^{+} & 0.36765 \\ y_{4}^{+} & 0.34483 \\ y_{5}^{+} & 0.27119\end{array}$

Hasil Perhitungan solusi ideal negatif menggunakan rumus :

$$
\begin{aligned}
& A^{+}=\left(y_{1}^{+}, y_{2}^{+}, \ldots, y_{n}^{+}\right) ; \\
& A^{-}=\left(y_{1}^{-}, y_{2}^{-}, \ldots, y_{n}^{-}\right) ;
\end{aligned}
$$

Tabel 18. Solusi ideal negatif
$y_{1}^{-}$
0.13187
$y_{2}^{-}$
0.10714
$y_{3}^{-}$
0.22059
$y_{4}^{-}$
0.13793
$y_{5}^{-}$
0.20339

Tabel 19. Jarak setiap alternatif terhadap solusi ideal positif

$$
D_{1^{+}} \quad 0.266385
$$

$\begin{array}{ll}\boldsymbol{D}_{\mathbf{2}^{+}} & 0.107845 \\ \boldsymbol{D}_{\mathbf{3}^{+}} & 0.236519 \\ \boldsymbol{D}_{\mathbf{4}^{+}} & 0.177439 \\ \boldsymbol{D}_{\mathbf{5}^{+}} & 0.215692\end{array}$

Tabel 20. Jarak setiap alternatif terhadap solusi ideal negatif

$\begin{array}{ll}\boldsymbol{D}_{\mathbf{1}^{-}} & 0.083870 \\ \boldsymbol{D}_{\mathbf{2}^{-}} & 0.257613 \\ \boldsymbol{D}_{\mathbf{3}^{-}} & 0.122902 \\ \boldsymbol{D}_{\mathbf{4}^{-}} & 0.177059 \\ \boldsymbol{D}_{\mathbf{5}^{-}} & 0.117304\end{array}$

Tabel 21. Nilai Preferensi setiap alternatif

$\begin{array}{ll}\boldsymbol{v}_{\mathbf{1}} & 0.239454 \\ \boldsymbol{v}_{\mathbf{2}} & 0.704905 \\ \boldsymbol{v}_{\mathbf{3}} & 0.341945 \\ \boldsymbol{v}_{\mathbf{4}} & 0.499464 \\ \boldsymbol{v}_{\mathbf{5}} & 0.352269\end{array}$

Dari perhitungan nilai preferensi, di peroleh nilai seperti tabel di atas. Pada tabel tersebut

$v_{2}$ merupakan nilai terbesar, sehingga $v_{2}$ adalah kandidat untuk guru terbaik.

\section{Perancangan Sistem}


Gambar 2. Perancangan Basis Data

\section{Use Case Diagram}


ISSN 2541-1004



Gambar 3 Use Case Diagram Admin

3. Activity Diagram



Gambar 4 Activity Diagram data Guru

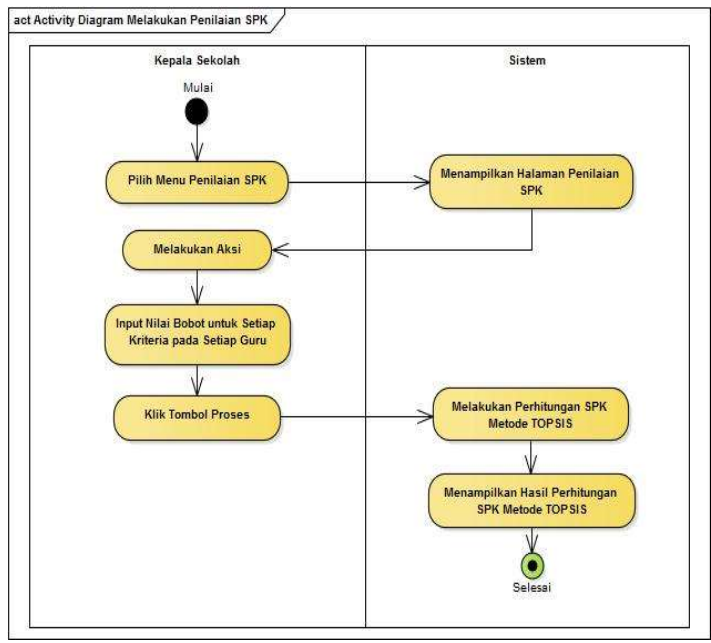

Gambar 5. Activity Diagram penilaian

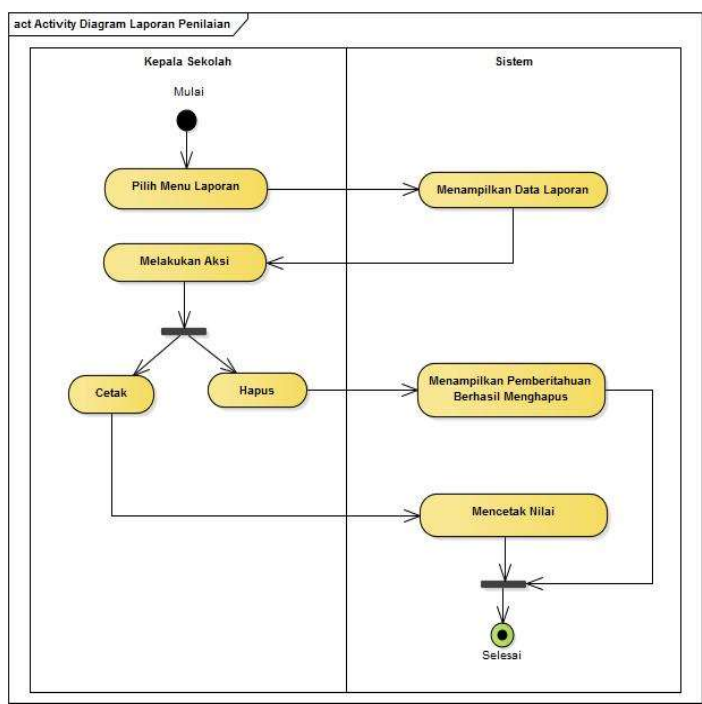

Gambar 6. Activity Diagram Laporan

4. Sequence Diagram



Gambar 7. Sequence Diagram Data Guru 




Gambar 8. Sequence Diagram Penilaian

\section{Class Diagram}

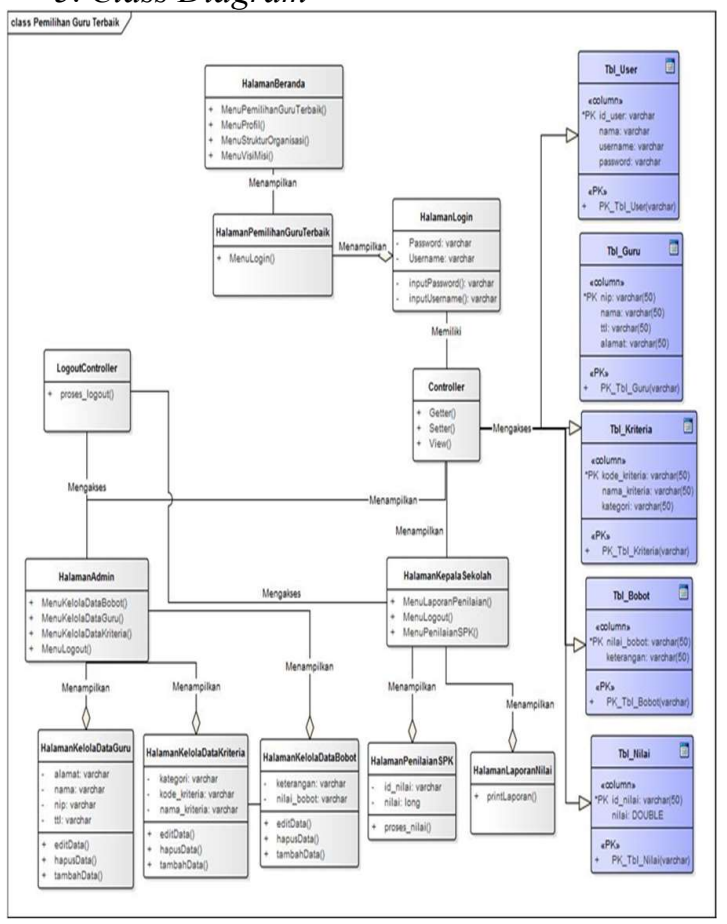

Gambar 9. Class Diagram

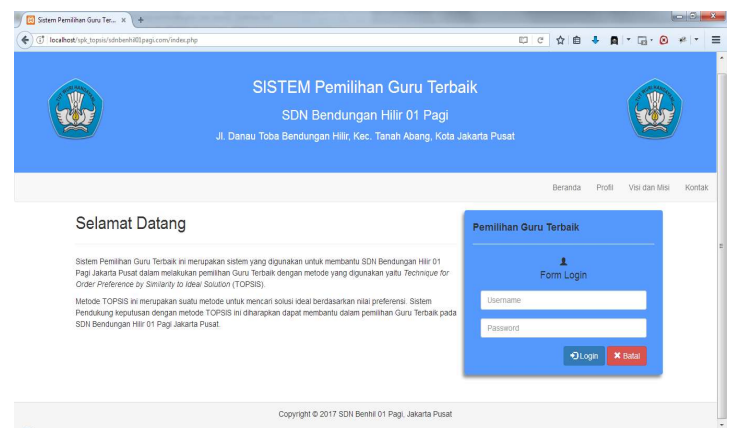

Gambar 10. Halaman Login

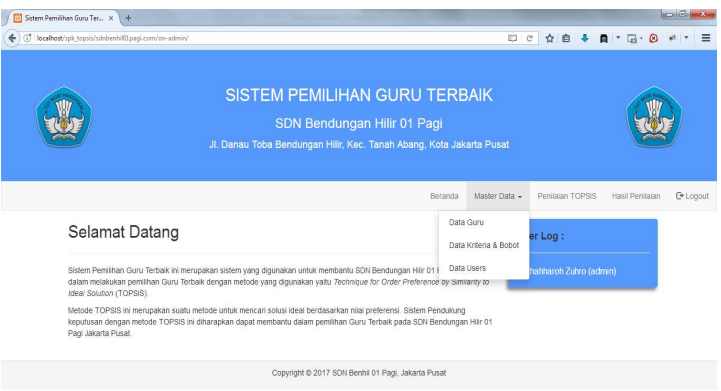

Gambar 11. Halaman Awal User

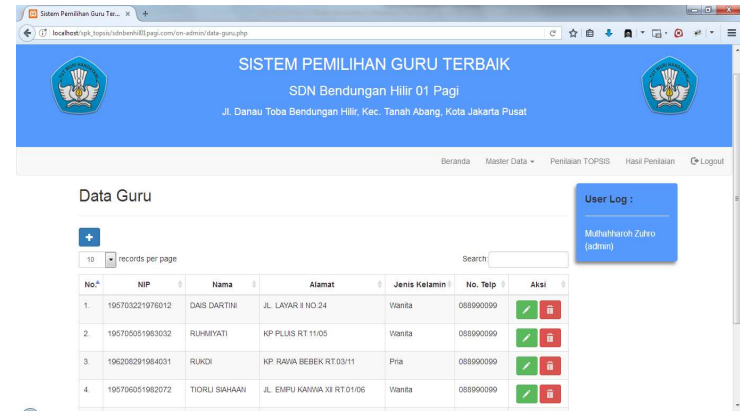

Gambar 12. Halaman data guru

Data Bobot

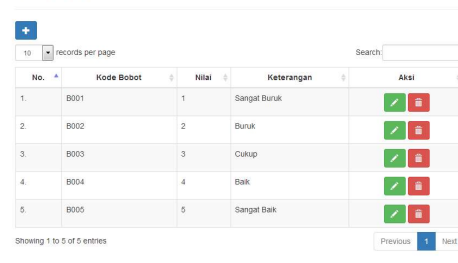

Gambar 13. Halaman data bobot

\section{User Interface}




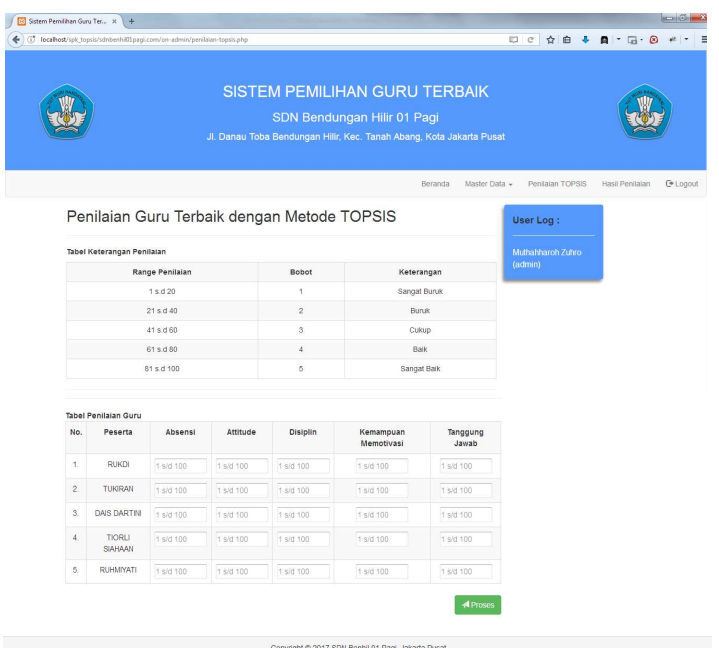

Gambar 14. Halaman Penilaian TOPSIS



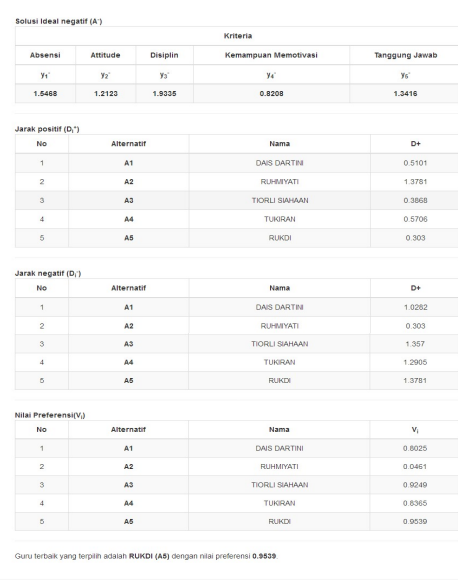

Gambar 15. Halaman hasil penilaian TOPSIS

\section{Pengujian}

1. Penjujian Black Box

Pengujian Blackbox merupakan pengujian software berfokus pada persyaratan fungsionalnya. Pengujian Sistem Pemilihan Guru Terbaik ini menggunakan data uji berupa data Input dari User pada sistem yang telah dibangun.

Tabel 22. Pengujian Black Box

\begin{tabular}{|l|l|}
\hline \multicolumn{1}{|c|}{ Item uji } & Jenis pengujian \\
\hline Login & Blackbox \\
\hline Kelola Data Guru & Blackbox \\
\hline $\begin{array}{l}\text { Kelola Data Kriteria \& } \\
\text { Bobot }\end{array}$ & Blackbox \\
\hline Kelola Data Users & Blackbox \\
\hline Penilaian TOPSIS & Blackbox \\
\hline Hasil Penilaian & Blackbox \\
\hline
\end{tabular}

Tabel 23. Pengujian Black Box Guru

\begin{tabular}{|c|c|c|c|}
\hline \multicolumn{4}{|c|}{ Kasus dan hasil uji (data benar) } \\
\hline Data yang dimasukan & Yang diharapkan & Pengamatan & Kesimpulan \\
\hline $\begin{array}{l}\text { Input data guru sesuai } \\
\text { dengan form input yang } \\
\text { tersedia pada form data } \\
\text { guru, kemudian klik } \\
\text { tombol Simpan }\end{array}$ & $\begin{array}{l}\text { Dapat memproses } \\
\text { dan menyimpan data } \\
\text { guru. }\end{array}$ & \begin{tabular}{|l|} 
Menampilkan \\
pesan Berhasil \\
Simpan Data dan \\
menampilkan data \\
pada tabel, seperti \\
yang diharapkan.
\end{tabular} & $\begin{array}{l}\text { (v) Diterima } \\
\text { () Ditolak }\end{array}$ \\
\hline \multicolumn{4}{|c|}{ Kasus dan hasil uji (data salah) } \\
\hline $\begin{array}{l}\text { Field input data di- } \\
\text { biarkan kosong lalu tekan } \\
\text { tombol Simpan. }\end{array}$ & \begin{tabular}{|lr} 
Tidak & dapat \\
memproses dan \\
menyimpan data.
\end{tabular} & \begin{tabular}{|l|} 
Menampilkan \\
pesan field input \\
harus diisi pada \\
field yang kosong.
\end{tabular} & $\begin{array}{l}\text { (v) Diterima } \\
\text { () Ditolak }\end{array}$ \\
\hline
\end{tabular}

Tabel 24. Pengujian Black Box Penilaian 


\begin{tabular}{|c|c|c|c|}
\hline \multicolumn{4}{|c|}{ Kasus dan hasil uji (data benar) } \\
\hline Data yang dimasukan & Yang diharapkan & Pengamatan & Kesimpulan \\
\hline $\begin{array}{l}\text { Inputdata penilaian lalu } \\
\text { tekan tombol Proses. }\end{array}$ & $\begin{array}{l}\text { Dapat memproses } \\
\text { penilaian. }\end{array}$ & \begin{tabular}{|lr}
\multicolumn{2}{|l}{ Menampilkan } \\
pesan Berhasil \\
Simpan Data \\
Penilaian, & seperti \\
yang diharapkan.
\end{tabular} & $\begin{array}{l}\text { (v) Diterima } \\
\text { () Ditolak }\end{array}$ \\
\hline \multicolumn{4}{|c|}{ Kasus dan hasil uji (data salah) } \\
\hline $\begin{array}{ll}\text { Form } & \text { Input } \\
\text { penilaiandibiarkan } & \\
\text { kosong lalu tekan } \\
\text { tombolProses. }\end{array}$ & \begin{tabular}{|lr} 
Tidak dapat \\
memproses \\
penilaian
\end{tabular} & $\begin{array}{l}\text { Menampilkan } \\
\text { pesanform } \\
\text { inputharus diisi. }\end{array}$ & $\begin{array}{l}\text { (v) Diterima } \\
\text { () Ditolak }\end{array}$ \\
\hline
\end{tabular}

Tabel 25. Pengujian Black Box hasil penilaian

\begin{tabular}{|c|c|c|c|}
\hline \multicolumn{4}{|c|}{ Kasus dan hasil uji (data benar) } \\
\hline Data yang dimasukan & Yang diharapkan & Pengamatan & Kesimpulan \\
\hline $\begin{array}{l}\text { Klik menu Hasil } \\
\text { Penilaian. }\end{array}$ & $\begin{array}{l}\text { Dapat menampilkan } \\
\text { hasil penilaian dan } \\
\text { angka-angka } \\
\text { penilaian. }\end{array}$ & $\begin{array}{l}\text { Menampilkandata } \\
\text { penilaian pada } \\
\text { tabel, seperti yang } \\
\text { diharapkan. }\end{array}$ & $\begin{array}{l}\text { (v) Diterima } \\
\text { () Ditolak }\end{array}$ \\
\hline \multicolumn{4}{|c|}{ Kasus dan hasil uji (data salah) } \\
\hline $\begin{array}{l}\text { Data Penilaian dibiarkan } \\
\text { kosong lalu tekan menu } \\
\text { Hasil Penilaian. }\end{array}$ & $\begin{array}{l}\text { Tidak dapat } \\
\text { memproses } \\
\text { perhitungan dan } \\
\text { penilaian TOPSIS. }\end{array}$ & \begin{tabular}{|l|} 
Menampilkan \\
ERROR, seperti \\
yang diharapkan.
\end{tabular} & $\begin{array}{l}\text { (v) Diterima } \\
\text { () Ditolak }\end{array}$ \\
\hline
\end{tabular}

2. Pengujian White Box

Pengujian Whitebox merupakan metode desain uji kasus yang menggunakan struktur control dari desain procedural untuk menghasilkan kasus-kasus uji. Pengujian Whitebox didesain untuk mengungkap kesalahan pada persyaratan fungsional tanpa mengabaikan kerja internal dari suatu software. Seperti yang terlihat pada tabel Whitebox testing di bawah ini:

Tabel 26. Pengujian white box login

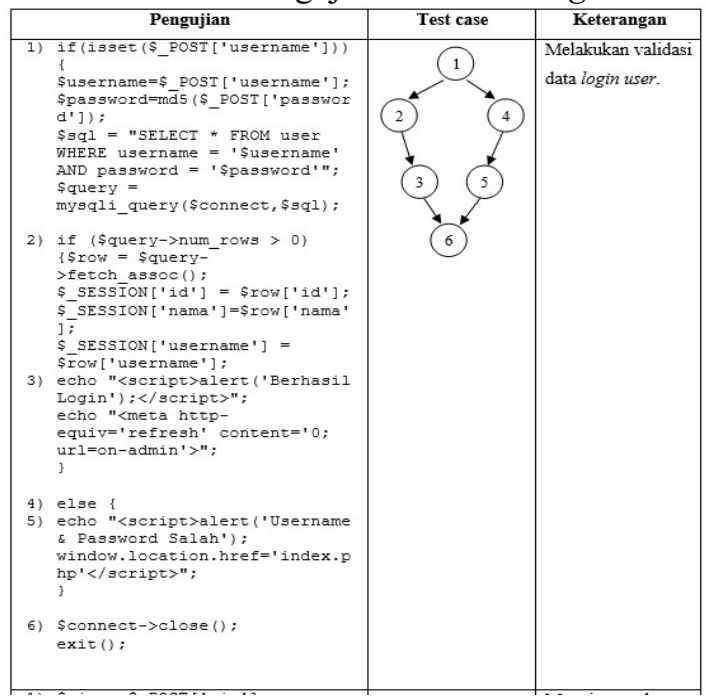

\section{KESIMPULAN}

Berdasarkan hasil perancangan, implementasi dan pengujian Sistem Pemilihan Guru Terbaik pada SDN Bendungan Hilir 01 Pagi Jakarta dengan menerapkan metode Technique for Order Preference by Similarity to Ideal Solution (TOPSIS) untuk melakukan pemilihan guru terbaik, maka dapat diambil kesimpulan sebagai berikut:

1. Perancangan dan pembangunan Sistem Pemilihan Guru Terbaik terbukti dapat membantu dalam melakukan pemilihan guru terbaik.

2. Penerapan metode Technique for Order Preference by Similarity to Ideal Solution (TOPSIS) terbukti dapat membantu dalam pengambilan keputusan pemilihan guru terbaik sesuai dengan nilai yang telah ditentukan.

\section{DAFTAR PUSTAKA}

Arbelia \& Paryanta, 2014. Penerapan Metode AHP dan TOPSIS Sebagai Sistem Penunjang Keputusan Dalam Menetukan Kenaikan Jabatan Bagi Karyawan. GO INFOTECH, 20(1), pp. 9-17.

Gunawan, S., 2015. Sistem Pendukung Keputusan Pemilihan Guru Terbaik Pada SMA Negeri 2 Kutacane dengan Menggunakan Metode Simple Additive Weighting (SAW). Pelita Informatika Budi Darma, Volume: IX, Nomor: 3, April 2015. ISSN: 2301-9425, pp. 143-148.

Kusumadewi, S. \& Hartati, S., 2006. Fuzzy Multi Attribute Decision Making (Fuzzy-MADM). Yogyakarta: Penerbit Andi.

Mallu, S., 2015. Sistem Pendukung Keputusan Penentuan Karyawan Kontrak Menjadi Karyawan Tetap Menggunakan Metode TOPSIS. Jurnal Ilmiah Teknologi Informasi Terapan, Volume I, No. 2, 30 April 2015. ISSN: 2407-3911, pp. 36-42.

Martaulina, 2015. Sistem Pendukung Keputusan Seleksi Guru Berprestasi Untuk Memberikan Penghargaan degan Metode TOPSIS. Jurnal Pelita Informatika Budi darma, IX(1), pp. 119124.

Shalahuddin, M. \& Rosa, A. A., 2011. Modul Rekayasa Perangkat Lunak (Terstruktur dan Berorientasi Objek). Bandung: Modula.

Shalahuddin, M. \& Rosa, A. A., 2014. Rekayasa Perangkat Lunak Terstruktur dan Berorientasi Objek. Bandung: Informatika Bandung.

Turban, E., 2005. Sistem Penunjang Keputusan dan Kecerdasan Buatan. Yogyakarta: Andi offset. 